\title{
ACUTE EFFECT OF AEROBIC EXERCISE OF DIFFERENT INTENSITIES IN CYTOKINES OF UNIVERSITY STUDENTS
}

\author{
EFEITO AGUDO DO EXERCICIO AERÓBICO DEDIFERENTES INTENSIDADES EM CITOCINAS \\ DE UNIVERSITÁRIOS
}

Original Articie

Artigo Original Artículo Original

\section{EFECTO AGUDO DEL EJERCICIO AERÓBICO DE DIFERENTES INTENSIDADES EN CITOQUINAS DE UNIVERSITARIOS}

\begin{abstract}
Beatriz Augusta Pozzolo' (D) (Physician)

Vanessa Ferrari da Fonseca' (ID (Physician)

Amanda Archeleiga Guedes' (ID (Physician)

Giovanna Lima de Oliveira' (ID (Physician)

Daniele Dietrich ${ }^{1}$ (D)

(Physician)

Eva Marco Lima' (ID

(Physician)

Taís Capucho Santos' 1 (ID

(Physician)

Fernanda Panacioni' (ID)

(Physician)

Fabiola lagher ${ }^{2}$ (DD

(Dentistry/Physiology)

Anderson Zampier Ulbrich ${ }^{1}$ (I)

(Physical Education Professional)
\end{abstract}

1. Universidade Federal do Paraná (UFPR), Health Sciences Sector, Department of Integrated Medicine, Research Group in Exercise Medicine (MedEx), Curitiba, PR, Brazil.

2. Universidade Federal do Paraná (UFPR), Biological Sciences Sector, Department of Physiology,

Curitiba, PR, Brazil.

\section{Correspondence:}

Anderson Zampier Ulbrich Rua Padre Camargo, 280, Alto da Glória, Curitiba, PR, Brazil. 80060-240

anderon_u@hotmail.com medexufpr@gmail.com

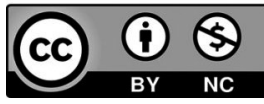

\begin{abstract}
Introduction: A single exercise training session promotes stimuli for changes in the immune system that are cumulatively considered adaptations to the exercise. Objective: This paper explores the acute effect of different intensities of aerobic exercise on anti-inflammatory and proinflammatory markers in apparently healthy university students. Methods: Eighteen volunteers underwent two sessions of aerobic exercise, the first at $65-70 \%$ estimated heart rate (HR), and after seven days, a second session at $80-85 \% \mathrm{HR}$. Before and after each session, venous blood was drawn, in order to analyze interleukin (IL) 6 and 10 in a Milliplex Kit. The participants' level of physical activity was determined using a questionnaire. For statistical comparisons, two-way ANOVA was used for the variables hemodynamics and perceived exertion. The cytokine results were compared through the Student's t-test for repeated measurements. The exclusion criteria were the practice of physical exercise and having drunk alcohol on the day before the intervention sessions, the presence of osteomioarticular conditions, and missing one of the sessions. Results: This study showed that IL-6 was not significantly decreased when comparing the two sessions. IL-10 was significantly decreased ( $p=0.033)$ in the $65-70 \% \mathrm{HR}$ session but not in the $80-85 \% \mathrm{HR}$ session. The delta variation for IL-10 showed a tendency $(p=0.053)$ towards a greater decrease in the $65-70 \% \mathrm{HR}$ session when compared to the $80-85 \% \mathrm{HR}$ session. There were no differences in the acute effect of exercise when comparing the levels of physical activity. Conclusion: This study highlights that two different zones of high intensity exercise can induce different inflammatory responses, as demonstrated by the significant decrease in IL-10 in the $65-70 \% \mathrm{HR}$ zone. The study also shows that there was no difference in physical exercise response in individuals with moderate and high physical activity levels. Level of evidence III; Comparative study.
\end{abstract}

Keywords: Interleukin-6; Interleukin-10; Inflammation.

\section{RESUMO}

Introdução: Uma única sessão de treinamento de exercício promove estímulos para mudanças no sistema imunológico que são cumulativamente consideradas como adaptações ao exercício. Objetivo: O presente estudo visa analisar o efeito agudo de diferentes intensidades de exercício aeróbico em marcadores pró e anti-inflamatórios de universitários jovens aparentemente saudáveis. Métodos: Para isso, dezoito universitários voluntários foram submetidos a duas sessões de exercício físico aeróbico, a primeira de $65 \%$ a $70 \%$ da frequência cardíaca (FC) estimada e sete dias depois, a uma segunda sessão a 80\% a 85\% da FC. Antes e depois de cada sessão, foi coletado o sangue venoso para análise das interleucinas (IL) 6 e 10 no Kit Milliplex. Avaliou-se o nivel de atividade física por questionário. Para comparações estatísticas, usou-se ANOVA two way, para as variáveis hemodinâmicas e de percepção de esforço. O resultado das citocinas foi comparado por meio de Teste t de Student para medidas repetidas. Foram considerados critérios de exclusão a prática de exercício e o uso de bebida alcoólica nos dias anteriores às sessões, a presença de alterações osteomioarticulares e a ausência em um dos dias de avaliação. Resultados: O estudo demonstrou que a ll-6 não diminuiu de forma significativa quando comparados os momentos nas sessões. A IL-10 reduziu significativamente $(p=0,033)$ na sessão de $65 \%-70 \%$ FC, mas não na de $80 \%$-85\% FC. O delta de variação da lL-10 apresentou tendência ( $p=0,053)$ de maior redução a 65\%-70\% FC em comparação com 80\%-85\%. Não houve diferenças no efeito agudo do exercício quando comparados os níveis de atividade. Conclusão: Dessa forma, evidenciou-se que duas faixas diferentes de exercício intenso podem induzir respostas inflamatórias diferentes, conforme evidenciado pela redução significativa da IL-10 na faixa de 65\%-70\% FC. Destacase também que não houve diferença na resposta ao exercício físico em indivíduos com nível moderado e intenso de atividade física. Nível de evidência Ill; Estudo comparativo.

Descritores: Interleucina-6; Interleucina-10; Inflamação.

\section{RESUMEN}

Introducción: Una única sesión de entrenamiento de ejercicio promueve estímulos para cambios en el sistema inmunológico que son acumulativamente considerados como adaptaciones al ejercicio. Objetivo: Este estudio tiene como objetivo analizar el efecto agudo de diferentes intensidades de ejercicio aeróbico en marcadores pro y 
antiinflamatorios de jóvenes universitarios aparentemente saludables. Métodos: Para eso, dieciocho universitarios voluntarios fueron sometidos a dos sesiones de ejercicio físico aeróbico, la primera de $65 \%$ a $70 \%$ de la frecuencia cardíaca (FC) estimada y siete días después, a una segunda sesión a 80 a 85\% de la FC. Antes y después de cada sesión, fue colectada sangre venosa para el análisis de interleucinas (IL) 6 y 10 en el kit Milliplex. Se evaluó el nivel de actividad física por cuestionario. Para comparaciones estadísticas, se usó ANOVA two way, para las variables hemodinámicas y de percepción de esfuerzo. El resultado de las citoquinas fue comparado por medio del Test t de Student para medidas repetidas. Fueron considerados criterios de exclusión la práctica de ejercicio y el uso de bebida alcohólica en los días previos a las sesiones, la presencia de alteraciones osteomioarticulares y la ausencia en uno de los días de evaluación. Resultados: El estudio demostró que la lL-6 no disminuyó de forma significativa cuando comparados los momentos en las sesiones. La lL-10 se redujo significativamente ( $p=0,033)$ en la sesión de 65-70\% de FC, pero no en la sesión de 80-85\% de FC. El delta de variación de IL-10 presentó tendencia ( $p=0,053)$ de mayor reducción a 65-70\% de FC en comparación con 80-85\%. No hubo diferencias en el efecto agudo del ejercicio cuando comparados los niveles de actividad. Conclusión: De esa forma, se evidenció que dos rangos diferentes de ejercicio intenso pueden inducir diferentes respuestas inflamatorias, conforme a lo evidenciado por la reducción significativa de IL-10 en el rango de 65-70\% de FC. Se destaca también que no hubo diferencia en la respuesta al ejercicio físico en individuos con nivel moderado e intenso de actividad física.

Nivel de evidencia III; Estudio comparativo.

Descriptores: Interleucina-6; Interleucina-10; Inflamación.

\section{INTRODUCTION}

A review study ${ }^{1}$ showed that pathologies are related to the higher level of pro-inflammatory mediators such as interleukin 6 (IL-6). Elevated levels of this cytokine are related to several forms of chronic inflammation, such as metabolic syndrome, coronary heart disease and various types of cancer. As mentioned by Nieman, ${ }^{2}$ the practice of long-distance physical exercises, such as marathons, disturb the immune system with transient elevations of IL-8 and IL-10, among other markers. A study published with 15 physically active men showed that changes in inflammatory mediators also occur after an acute exercise session, with a more significant increase in IL-6 after the high intensity session. ${ }^{2}$

However, although athletes face regular elevations of these mediators, their baseline levels are lower than in overweight or sedentary individuals. ' Even non-athletes who maintain vigorous physical activity levels are $47 \%$ less likely to have high concentrations of pro-inflammatory markers. ${ }^{3}$ Furthermore, there is an inverse correlation between days practicing physical exercise and baseline IL-6 levels. ${ }^{4}$

The literature lacks studies comparing healthy young non-athletes with low, moderate and high physical activity levels (PAL) after two acute sessions of short-term exercise.

This study sought to analyze the acute effect of different intensities of aerobic exercise on pro- and anti-inflammatory markers from apparently healthy young university students. We hypothesise that individuals with lower level of physical activity will have higher levels of pro-inflammatory markers at higher intensities and cytokine levels will differ between both intensities.

\section{MATERIALS AND METHODS}

\section{Study design and sample}

This is a short-duration experimental study that sought to verify the effect of an acute intervention on determinants for the health of young adults. The study was developed at the School Unit for Health Promotion (UE-PS/UFPR). The research participants were young adults entering the medical course, enrolled in a public university in southern Brazil; invitations to take part in the study were simple and sent randomly (Figure 1). The informed consent form was signed by all research participants before the intervention.

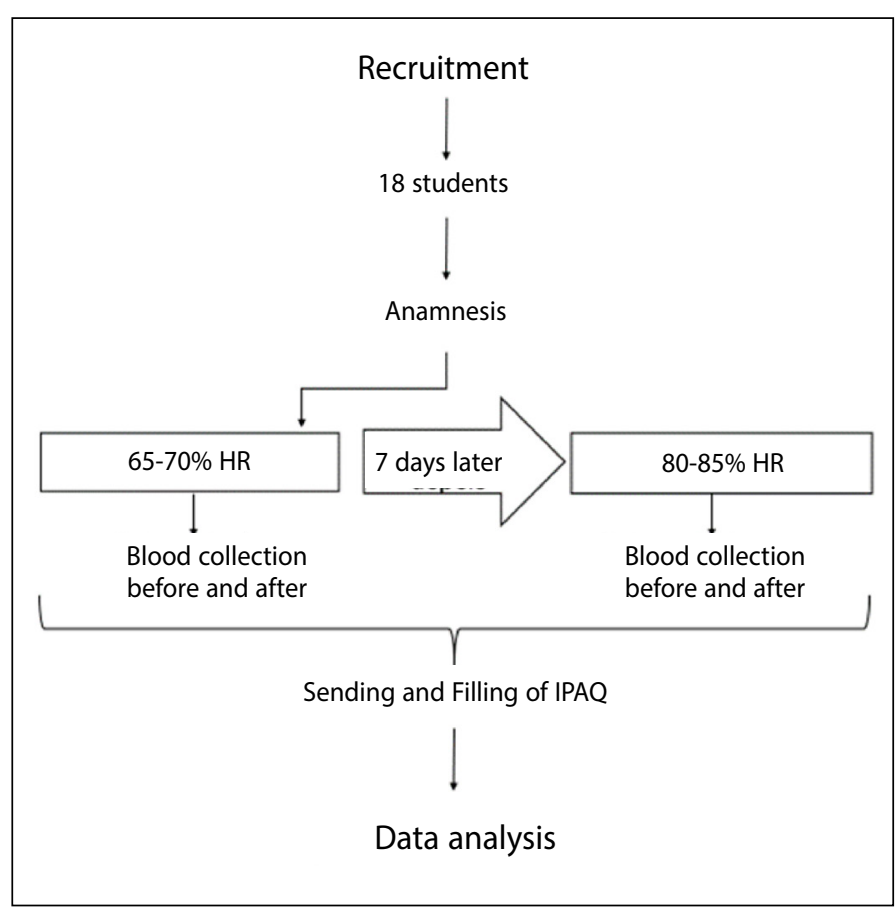

Figure 1. Flowchart for recruitment, logistics and intervention of the study.

Exclusion criteria were practice of physical exercise and use of alcoholic beverages in the days prior to sessions; presence of musculoskeletal alterations; and missing one of the evaluation days.

The study was evaluated by the Research Ethics Committee of the Health Sciences Sector of the Federal University of Paraná (UFPR), which follows Resolution 466/12 of the National Health Council, and is in accordance with the Helsinki World Medical Declaration of 1975 on ethics in medical research (CAAE: 71645617.4.0000.0102).

\section{Instruments and procedures}

\section{Blood collection protocol and cytokine analysis}

Venous blood was collected always in the morning. Samples were collected before (rest) and immediately after the exercise sessions. The same procedures were used in both sessions. Two blood tubes were collected with EDTA (Sarstedt Monovette, Sarstedt AG, Numbrecht, 
Germany), each with $7.5 \mathrm{ml}$ in volume. The tubes underwent centrifugation for plasma separation, from which cytokines were quantified.

After collection, the biological material was transported, separated from plasma and stored in a freezer $\left(-80^{\circ} \mathrm{C}\right)$ for further analysis of the markers under study. Cytokine analyses were carried out in partnership with the Multi-User Experimental Laboratory of the Pontifical Catholic University of Paraná (PUC-PR). Plasma cytokine levels were measured by immunoenzymatic assay on the MAGPIX Luminex equipment, according to recommendations of the kit manufacturer (MILLIPLEX MAG Human Cytokine/Chemokine Magnetic Bead Panel; @ EMD Millipore Corporation, Billerica, MA, USA), together with the Luminex XMAPه platform in the form of magnetic spheres. The following cytokines were analyzed: IL-6 and IL-10.

\section{Assessment of Physical Activity Level (PAL)}

The Physical Activity Level was evaluated through the International Physical Activity Questionnaire (IPAQ), short version, self-applied, through a form sent by e-mail to participants. The questionnaire classifies individuals into three categories of physical activity level: mild, moderate and high. A study published in the Brazilian Journal of Physical Activity and Health concluded that IPAQ seems to have validity and reproducibility similar to that of other instruments used internationally to measure the level of physical activity and that there are no important differences between interview procedures - by phone and self-applicable. This same study concluded that both short and long forms presented similar validity and reproducibility results, the short form being best accepted by participants due to its practicality. ${ }^{5}$

\section{Intervention: aerobic exercise at different intensities}

Participants were invited to perform two sessions of continuous aerobic physical exercises at different intensities, but with a seven-day interval between them. The interventions were performed after all the evaluation procedures mentioned above, lasting approximately 40 minutes at $65-70 \%$ of heart rate (HR), by Karvonen Formula ${ }^{6}$, and then at $80-85 \% \mathrm{HR}$.

All procedures were performed on an indoor bicycle (Schwinn AC Sport - VancouverWA, USA), with collection of HR, rotations per minute (70-80 rpm) and adjustable load according to the subject's cardiovascular response. The proposed intensities were determined according to Karvonen Formula. The volunteer's HR was controlled during practice using a cardiac monitor (Polar FT1, Polar Electro Oy, Kempele, Finland). Blood pressure was assessed before, during (every ten minutes) and after the end of each session (after 1 minute and 5 seconds).

The perceived level of effort was evaluated every 10 minutes of exercise and five minutes after its completion according to the adapted Borg Scale? In the first session, the participant was submitted, in the specific part of the intervention, to an aerobic exercise at 65-70\% HR, by Karvonen Formula. The student was submitted to the same type of exercise after a seven-day interval to avoid possible physiological interferences caused by the first session, but at 80-85\% HR intensity. Before and after each session, blood collection was performed to obtain the desired variables.

\section{Statistical analysis}

Statistical analysis comprised an initial normality test (Shapiro Wilk). Then, sociodemographic data were analyzed through central tendency measures (mean and standard deviation). Frequency analysis was used to determine the prevalence of subjects with mild, moderate and high physical activity levels.

The effect of interventions on Subjective Perception of Exertion (Borg) and hemodynamic variables was compared using two-way Analysis of Variance (Two-Way ANOVA). The comparison between the different exercise intensities was determined from Student's $t$-Test for repeated measurements. The same test was also used to compare the concentration of cytokines between the different PAL for independent measures. All analyses were performed in the SPSS software for Windows, version 20.0, and significance was considered when $p<0.05$. The graphs were plotted in the GraphPad Prisma software for Windows, version 6.01 (GraphPad Software, Inc., USA).

\section{RESULTS}

Of the 18 participants who volunteered to the research, 4 did not complete all stages of the intervention and were excluded from the sample (on the second day of the intervention, two presented health problems during the exercise session and two did not attend). Table 1 shows the anthropometric characteristics of the 14 subjects who completed the entire experimental protocol.

Figure 2 shows the PAL of the participants, being predominantly moderate.

The effect of exercise sessions on IL- 6 and IL-10 are highlighted in Figure 3. IL-10 showed a significant 228\% reduction in the $65-70 \% \mathrm{HR}$ session ( $p=0.033$ ), but there was no statistically significant difference $(\Delta \%=-32 \%)$ in the $80-85 \%$ HR session. (Figure 3-B). There was, however, a tendency ( $p=0.053$ ) for a difference on the variation delta between the $65-70 \% \mathrm{HR}$ and $80-85 \% \mathrm{HR}$ sessions.

There was no statistically significant difference in pre- and post-exercise between individuals with moderate and high physical activity level. (Figure 4)

Table1. Descriptive characteristics of the university students.

\begin{tabular}{c|c}
\hline Data & $\mathbf{N}=\mathbf{1 4}$ \\
\hline Age (years) & $23.67 \pm 2.85$ \\
\hline Weight $(\mathrm{kg})$ & $65.93 \pm 10.94$ \\
\hline Height $(\mathrm{cm})$ & $169.9 \pm 7.52$ \\
\hline BMl $\left(\mathrm{kg} / \mathrm{m}^{2}\right)$ & $22.72 \pm 2.70$ \\
\hline
\end{tabular}

Values expressed in mean \pm standard deviation; Abbreviations: BMl: body mass index.

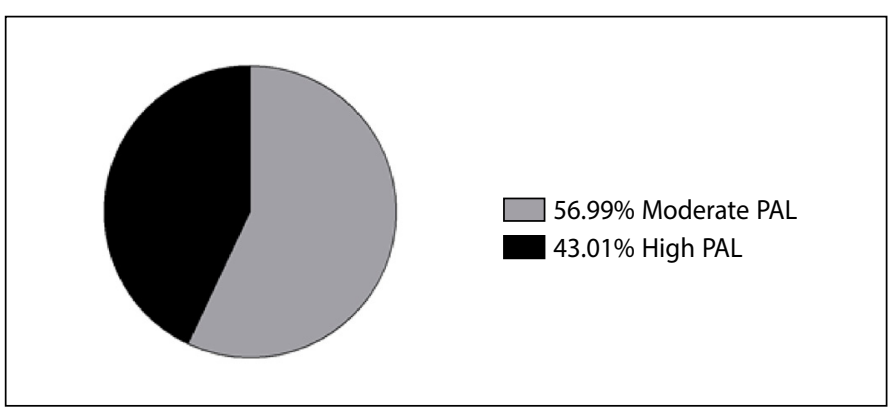

Figure 2. Physical activity level of the university students evaluated.

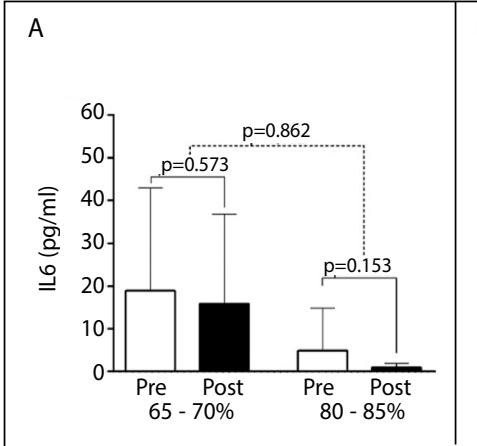

B

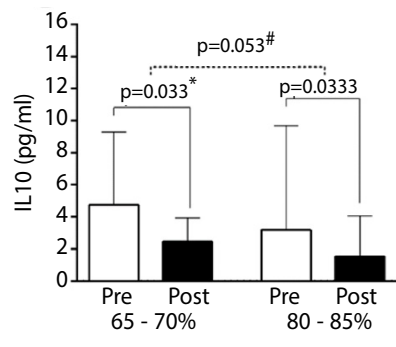

A- Variation of IL- 6 before and after physical exercise. B- Variation of IL-10 before and after physical exercise * represents the significant difference before and after; \# represents the significant difference in the deltas of variation between intensities.

Figure 3. Interleukins variation at different physical exercise intensities in the university students. 


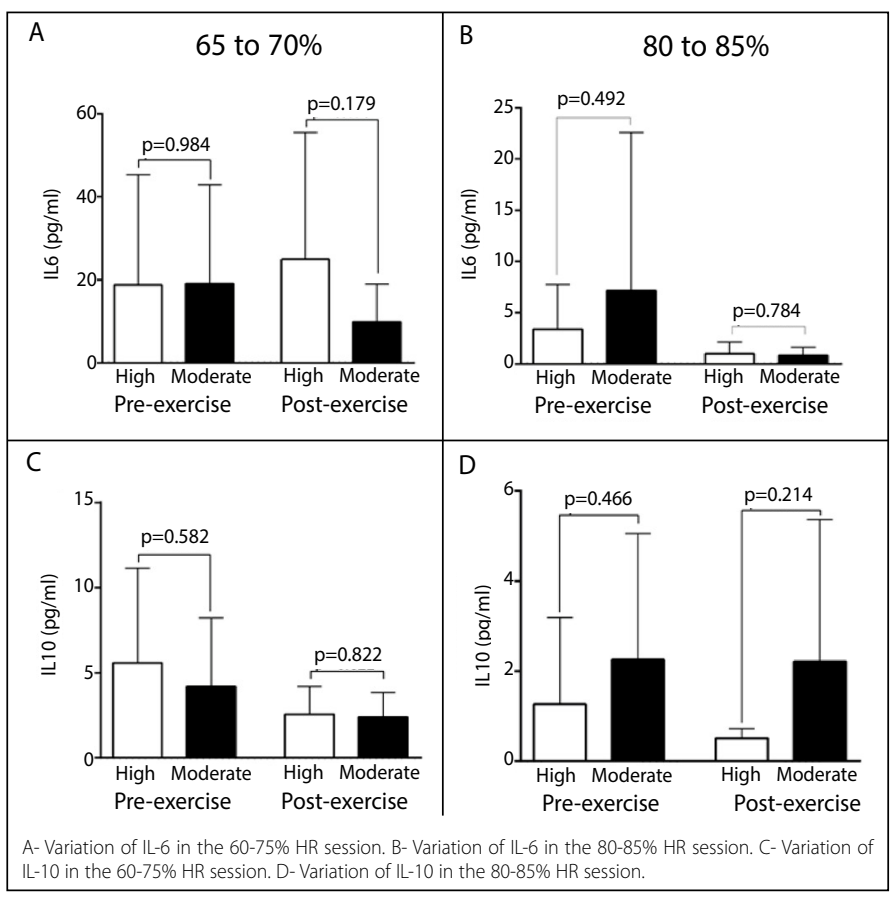

Figure 4. Percentage of moderate and high physical activity level among subjects.

\section{DISCUSSION}

IL-6 did not decrease significantly when comparing the moments in sessions. IL-10 reduced significantly ( $p=0.033$ ) in the $65-70 \% \mathrm{HR}$ session, but not in the $80-85 \%$ HR session. The IL-10 delta of variation showed a tendency $(p=0.053)$ of greater reduction at $65-70 \%$ HR when compared to $80-85 \%$. There were no differences in the acute effect of exercise when comparing physical activity levels.

In a study conducted with 20 physically active individuals, IL-6 increased in the high intensity session compared to the low intensity session. ${ }^{2}$ However, our results showed that IL-6 did not vary between the pre- and post-exercise periods in both sessions (65-70\% HR and 80$85 \% \mathrm{HR}$ ), neither in the comparison between one session and another, as Figure 3-A shows.

A study in which IL-6 was collected 15 minutes after exercise showed an acute increase in this interleukin; however, the experimental study was performed differently, with fasting before exercise and several sessions of short duration aerobic exercise. ${ }^{8}$

When considering the PAL (moderate vs high) as a differentiating factor between the research subjects, there were no differences in the circulating concentration of IL-6 between the above mentioned categories at the time of interventions (baseline and post-exercise). However, Shanely et al. (2013) ${ }^{4}$ demonstrated that the higher the PAL, the lower the levels of basal IL-6. Our result may be due to the age range covered by the study (19-32 years), which is more restricted when compared to the other study, ${ }^{4}$ and, therefore, with less influence of intercurrent diseases, since individuals with diseases were included in this 2013 study.

Another study carried out with older individuals, apparently healthy, also found no difference between the groups of higher and lower physical activity in the IL-6 levels after acute exercise. ${ }^{9}$ Therefore, these results suggest there is no difference in the acute effect of physical exercise among individuals with moderate and high physical activity levels.
Contrary to our hypothesis, IL-10 faced a significant $228 \%$ reduction in the $65-70 \%$ HR session. (Figure 3-B) There was a tendency $(p=0.053$ ) for differences to occur between the variation delta between the $65-70 \%$ and the $80-85 \%$ HR sessions, a result compatible with another study mentioned above, ${ }^{2}$ in which there was a decrease in IL-10 in the lower intensity session compared to the higher intensity session. These results suggest that borderline values of the same aerobic exercise intensity can produce different immune responses.

Different studies show an increase in the circulating concentration of IL-10 after an acute session of moderate ${ }^{10}$ and high intensity ${ }^{11}$ exercise. When the chronic effect of exercise is taken into account, two controlled studies have shown an $\mathrm{L}-10$ reduction in individuals undergoing aerobic training. ${ }^{12}$ Therefore, one hypothesis is that the regular and previous physical activity of participants may have interfered, even with the 24hour interval without physical activity.

Moore et al. (2001) describe the control of IL-10 over inflammatory reactions, which can be derived from physical exercise and also inhibit changes mediated by TNF-a (pro-inflammatory). ${ }^{13}$ A possible explanation for the significant $228 \%$ reduction of at $65-70 \%$ intensity is that this is the lowest production of this interleukin in the exercise performed, since tissue damage may not have occurred in a sufficient degree to maintain $\mathrm{L}-10$ at the same levels as the baseline.

Possible limitations of our study were uncontrolled factors such as diet, emotional stress, type of physical exercise practiced regularly. The research protocol tried to reach as many individuals as possible, excluding only those with osteomioarticular diseases and recent use of anti-inflammatory drugs. Another possible limitation may have been the analysis of blood collected immediately after exercise, which also showed no variation in other studies. ${ }^{14}$

\section{CONCLUSION}

From our results, we conclude that two different ranges of intense exercise can induce different inflammatory responses, as evidenced by the statistically significant IL-10 reduction in the $65-70 \% \mathrm{HR}$ range, which was not observed in the $80-85 \% \mathrm{HR}$ range. We can thus see that the less intense the exercise, the higher the decrease in anti-inflammatory response and that there is no change in anti-inflammatory activity when the intensity of the exercise is increased. It is also noteworthy that there is no difference in the response to physical exercise in individuals with moderate and high physical activity levels. Based on this data, we consider that the interleukins evaluated cannot be used as an important parameter to differentiate individuals with different PAL. However, further studies are needed to define the effect of a short duration continuous aerobic exercise on healthy adults.

\section{ACKNOWLEDGMENTS}

We would like to thank the collaborators of the Exercise Medicine Research Group (MedEx/UFPR), as well as the collaboration of Professor Andrea Moreno-Amaral and Natalia Borges Bonan of the Multi-User Experimental Laboratory of the Pontifical Catholic University of Paraná (PUC-PR), for their collaboration in the cytokines analysis. We would also like to thank the National Council for Scientific and Technological Development (CNPq) for financing the study through the Universal Call for Proposals (01/2016- Faixa A).

All authors declare no potential conflict of interest related to this article

AUTHORS' CONTRIBUTIONS: Each author made significant individual contributions to this manuscript. All the authors were responsible for the study design, writing, revision and final version. In the acquisition, analysis or interpretation of the data for the work, only Professor Fabiola lagher did not take part. 


\section{REFERÊNCIAS}

1. Nieman DC. Clinical implications of exercise immunology. J Sport Health Sci. 2012;1(1):12-7.

2. Neves PRS, Tenório TRS, Muniz MTC, Valle Neto LM, Botero JP, Oyama LM, et al. Efeitos de diferentes intensidades de exercício sobre a concentração sérica de interleucinas Rev Bras Educ Fís Esporte. 2014;28(4):545-52.

3. Ford ES. Does exercise reduce inflammation? Physical activity and C-reactive protein among U.S. adults. Epidemiology. 2002;13(5):561-8.

4. Shanely RA, Nieman DC, Henson DA, Jin F, Knab AM, Sha W. Inflammation and oxidative stress are lower in physically fit and active adults. Scand J Med Sci Sports. 2013;23(2):215-23.

5. Matsudo SMTAV. Questionário internacional de atividade física (IPAQ): estudo de validade e reprodutibilidade no Brasil. Rev Bras Ativ Fís Saúde. 2001;6(2):5-18.

6. Katch FIM. Nutrição, exercício e saúde 4ed. Rio de Janeiro: Medsi; 1996.

7. Borg G. Borg's Perceived Exertion and Pain Scales. Champaign, IL: Human Kinetics; 1998.

8. Meyer T, Gabriel HH, Ratz M, Muller HJ, Kindermann W. Anaerobic exercise induces moderate acute phase response. Med Sci Sports Exerc. 2001;33(4):549-55.
9. Windsor MT, Bailey TG, Perissiou M, Meital L, Golledge J, Russell FD, et al. Cytokine Responses to Acute Exercise in Healthy Older Adults: The Effect of Cardiorespiratory Fitness. Front Physiol. 2018;9:203.

10. Lira FS, Dos Santos T, Caldeira RS, Inoue DS, Panissa VLG, Cabral-Santos C, et al. Short-Term High- and Moderate-Intensity Training Modifies Inflammatory and Metabolic Factors in Response to Acute Exercise. Front Physiol. 2017;8:856.

11. Dorneles GP, Haddad DO, Fagundes VO, Vargas BK, Kloecker A, Romao PR, et al. High intensity interval exercise decreases IL- 8 and enhances the immunomodulatory cytokine interleukin-10 in lean and overweight-obese individuals. Cytokine. 2016;77:1-9.

12. Conroy SM, Courneya KS, Brenner DR, Shaw E, O'Reilly R, Yasui Y, et al. Impact of aerobic exercise on levels of IL-4 and IL-10: results from two randomized intervention trials. Cancer Med. 2016;5(9):2385-97.

13. Moore KW, de Waal Malefyt R, Coffman RL, O'Garra A. Interleukin-10 and the interleukin-10 receptor. Ann Rev Immunol. 2001;19:683-765.

14. Meksawan K, Venkatraman JT, Awad AB, Pendergast DR. Effect of dietary fat intake and exercise on inflammatory mediators of the immune system in sedentary men and women. J Am Coll Nutr. 2004;23(4):331-40. 